\title{
Endopolygalacturonase Gene Polymorphisms: Asset of the Locus in Different Peach Accessions
}

\author{
Silvia Morgutti, Noemi Negrini*, Alessandra Ghiani, Federica Baldin, Daniele Bassi, \\ Maurizio Cocucci \\ Department of Agricultural and Environmental Sciences-Production, Landscape, Agroenergy (DISAA), University of Milan, \\ Milan, Italy \\ Email: ^noemi.negrini@unimi.it
}

How to cite this paper: Morgutti, S., Negrini, N., Ghiani, A., Baldin, F., Bassi, D. and Cocucci, M. (2017) Endopolygalacturonase Gene Polymorphisms: Asset of the Locus in Different Peach Accessions. American Journal of Plant Sciences, 8, 941-957. https://doi.org/10.4236/ajps.2017.84063

Received: January 20, 2017

Accepted: March 28, 2017

Published: March 31, 2017

Copyright $\odot 2017$ by authors and Scientific Research Publishing Inc. This work is licensed under the Creative Commons Attribution-NonCommercial International License (CC BY-NC 4.0). http://creativecommons.org/licenses/by-nc/4.0/

\begin{abstract}
Endopolygalacturonase (endoPG) plays a pivotal role in determining peach [Prunus persica L. (Batsch)] fruit characteristics. Different $P p$-endoPG genes or allelic variants have been described, characterized by different polymorphisms: insertions-deletions (InDels) and single nucleotide polymorphisms (SNPs). Eighty-five peach accessions (comprising commercial cultivars, $\mathrm{F}_{1}$ progenies of selected crosses, and three haploid seedlings) with different flesh softening patterns (Non Melting: NM; Melting: M; Slow Softening: SS; Stony Hard: SH) were screened by exploiting specific polymorphisms, with the aim to characterize their asset at the endoPG locus and evaluate a potential relationship with fruit flesh texture phenotype. The results of InDel analysis allowed to distinguish, by a simple genotyping procedure, NM flesh phenotypes from the others. Further information arose from this analysis, showing that two $P p$-endoPG genes, i.e., $P p$-endoPG $G^{m}$ (Ppa006839m), involved in the determination of the Melting/Non Melting trait, and $P p$-endoPG_M(Ppa006857m), involved in the determination of the Clingstone/Freestone trait, always co-segregate, and that SS Big Top possesses a "null" $P$ p-endoPG allele. Cleaved Amplified Polymorphic Sequence (CAPS) analysis allowed to preliminarily discriminate the $P p$-endoPG variants of the SS and SH accessions considered. The integrated use of the considered polymorphisms in a high number of peach accessions proved useful, by individuating the different gene variants and their combinations, to describe the structure of the endoPG locus in different genotypes.
\end{abstract}

\section{Keywords}

CAPS Analysis, InDel/SNP Polymorphisms, Pp-endoPG, Prunus persica

\section{Introduction}

Flesh texture and stone adherence are important factors of the overall quality of 
the peach [Prunus persica (L.) Batsch] fruit, contributing to the consumer's satisfaction, fruit nutritional features, and postharvest behavior [1] [2].

Peaches are classified on the basis of their different flesh softening behavior during ripening. In Melting (M) flesh, a marked and steep loss of firmness ("melting" phase) occurs in the final stages of ripening. The melting process is delayed in Slow Softening (SS) fruit and undetectable in Non Melting (NM) and Stony Hard (SH) ones [2] [3] [4] [5] [6]. The SS phenotype is very interesting, retaining flesh firmness on the tree for longer time than standard $\mathrm{M}$, with full development of sensory qualities, and remarkable keeping quality appreciated by both growers and consumers. The spontaneous occurrence of melting, although a few days later than standard $M$, allows to group SS fruit into the M phenotype, since the physiological basis of SS is due to a delay in ethylene production [6]. Unfortunately, this phenotype, like the $\mathrm{SH}$ one, is of very difficult assessment on the tree when scoring segregating progenies [7].

Fruit flesh texture is affected by biochemical and physiological factors with a major role played by hydrolytic enzymes and other proteins that cooperate to modify the composition and architecture of the cell wall polysaccharides [8] [9]. In particular, peach flesh melting has been related to a strong increase in the expression of $P$-endopolygalacturonase ( $P$-endoPG) and accumulation of an active Pp-endoPG protein. In NM fruit, Pp-endoPG is absent or detected at levels lower than in $\mathrm{M}$ ones [5] [10] [11] [12]. Therefore, $P p$-endoPG is considered as a candidate gene for peach flesh softening behavior [13].

In eukaryotic organisms, Insertion-Deletion (InDel) and Single Nucleotide Polymorphisms (SNPs) represent the most abundant DNA mutations ([14] and references therein) that can modify the amplification patterns of selected DNA sequences as well as the restriction endonuclease recognition sites in PCR amplicons, allowing the development of markers useful for genotyping even in the absence of massive sequencing data ([15] and references therein).

In peach, availability of different molecular markers allowed to gain information on some 760 Quantitative Trait Loci and Mendelian Trait Loci linked to horticultural and physiological traits such as tree development, pest and disease resistance, flowering, ripening, seed and fruit quality [16] [17].

The availability of the peach genome sequence [18] and the development of SNP genotyping resources [19] [20] offer the opportunity to study at the molecular level the development and inheritance of different phenotypic traits, as recently reported for skin blush [21].

A high degree of allelic diversity has been identified in the peach $P p$-endoPG sequence [13] [22] [23]. We previously identified specific SNPs in the open-reading frame of $P p$-endoPG, one of which allowed to determine the configuration at the Melting flesh locus in the NM (Oro A) and M (Bolero) model cultivars, and in a few $\mathrm{M}$ and $\mathrm{NM} \mathrm{F}_{1}$ seedlings from their cross [5] [24]. Moreover, in Bolero (M), Oro A (NM), and in the cultivars Big Top (SS), Yumyeong ( $\mathrm{SH}$ ), and Ghiaccio ( $\mathrm{SH})$, representative of different flesh textures, 
variants of the $P p$-endoPG gene characterized by peculiar InDels and SNPs have been individuated. The $P p$-endoPG locus on chromosome 4 contains two sequences, i.e., $\mathrm{F}^{\mathrm{a}}$-Ppa006839m (GenBank ID: 18781156) and $\mathrm{F}^{\mathrm{b}}$-Ppa006857m (GenBank ID: 18779267), that coincide with $P p$-endoPG ${ }^{m}$ (GenBank ID: DQ659240.1) and $P p$-endoPG_M (GenBank ID: DQ659241.1) [6] [18] [23]. $\mathrm{F}^{\mathrm{a}}$ - $P$ pa006839m $\left(P p\right.$-endoP $\left.G^{m}\right)$, the only sequence retrieved in Oro A, shows $97 \%$ identity with its variants $P p$-endoPG $G^{S H}$ (GenBank ID: HQ891822.1 of SH Yumyeong and GenBank ID: HQ891821.1 of SH Ghiaccio) and $P p$-endoPG $G^{B T}$ (GenBank ID: HQ891820.1 of SS Big Top), for the presence in the latter ones of one 17-bp intronic deletion. Moreover, the Big Top-specific $P p$-endoPG ${ }^{B T}$ sequence shows a peculiar SNP (bp 348) in Exon 1, that does not induce any change in the deduced amino acidic sequence [6]. $\mathrm{F}^{\mathrm{b}}-P p a 006857 \mathrm{~m}$ ( $P$ p-endoPG_M), present in Bolero together with $\mathrm{F}^{\mathrm{a}}-\mathrm{Ppa006839m}$, is by $34 \mathrm{bp}$ shorter than $P p$-endoPG $G^{m}$, for the presence of one additional 17-bp intronic deletion. On this basis, amplification of a selected (1455-1892 bp) $P p$-endoPG genomic sequence including these InDels generates fragments specifically referable to $\mathrm{F}^{\mathrm{a}}$-Ppa006839m ( $P$-endoPG $\left.G^{m} ; 437 \mathrm{bp}\right)$, to its variants $P p$-endoPG $G^{S H}$ and $P p$-endoPG $G^{B T}$ (both of $420 \mathrm{bp}$ ), or to $\mathrm{F}^{\mathrm{b}}$-Ppa006857m (Pp-endoPG_M; $403 \mathrm{bp}$ ) [6]. $\mathrm{F}^{\mathrm{a}}$-Ppa006839m has recently been proposed as the main responsible for the Melting trait [23].

In the present work the InDel and the CAPS (Cleaved Amplified Polymorphic Sequence) markers developed from the described polymorphisms have been exploited to screen a total of 85 accessions (commercial cultivars, $F_{1}$ offsprings from selected crosses, and three haploids) to describe them for the configuration at the endoPG locus and evaluate a potential relationship with fruit flesh texture phenotype.

\section{Materials and Methods}

\subsection{Plant Material}

The study was conducted on commercial cultivars or on $\mathrm{F}_{1}$ offsprings of different crosses. Three haploid accessions (P VIN $11 \mathrm{~N}$ from Vineland, P RRL 1 1N from Rutgers Red Leaf, P LOV $31 \mathrm{~N}$ from Lovell) were also considered (Table 1).

Plant material was obtained from a peach germplasm collection grown at the Experimental Orchard "Zabina" (Castel San Pietro Terme, Italy; lat. $44^{\circ} 23^{\prime} 52^{\prime \prime N}$; long. $11^{\circ} 35^{\prime} 22^{\prime \prime} \mathrm{E}$ ), under the weather and climate conditions detailed in Table 2. Trees were grafted on GFF677 rootstock planted at $3.5 \times 4.5 \mathrm{~m}$ and trained as open vase. Seedlings were planted on their own roots with a spacing of $1 \mathrm{~m}$ within and $4 \mathrm{~m}$ between rows and trained as slender spindle (one stem with short lateral scaffolds). Pruning was performed yearly and standard cultural practices were applied.

\subsection{Fruit Flesh Texture Phenotype Scoring}

Flesh texture was scored in the orchard by trained personnel on fruit harvested at commercial ripening (onset of the veraison stage), as identified in each 
Table 1. List of the Prunus persica accessions used, with fruit flesh texture phenotype, pedigree, estimated length of endoPG-derived amplicons, and asset at the endoPG locus as hypothesizable by InDel analysis or, where available, reported in the literature. M: Melting; NM: Non Melting; SH: Stony Hard; SS: Slow Softening. NC, not classifiable. OP, open pollination. -, lack of fruit production.

\begin{tabular}{|c|c|c|c|c|c|c|}
\hline \multirow[t]{3}{*}{ Nr. } & \multirow[t]{3}{*}{ Accession } & \multirow[t]{3}{*}{$\begin{array}{c}\text { Flesh } \\
\text { Phenotype }\end{array}$} & \multirow[t]{3}{*}{ Pedigree } & \multicolumn{3}{|c|}{ EndoPG } \\
\hline & & & & Amplicons length & & asset \\
\hline & & & & & InDel analysis & Literature \\
\hline 1. & Andross & NM & Dix 5 A- $1 \times$ Fortuna & 440 & $\mathrm{fl} / \mathrm{f} 1 ; \mathrm{fl} / \mathrm{f}_{\text {null }}$ & $\mathrm{f} 1 / \mathrm{f} 1 ; \mathrm{f} 1 / \mathrm{f}_{\text {null }}[31]$ \\
\hline 2. & BO 82010554 & NM & Jungerman $\times$ Loadel & 440 & $\mathrm{f} 1 / \mathrm{f} 1 ; \mathrm{f} 1 / \mathrm{f}_{\text {null }}$ & - \\
\hline 3. & Ionia & NM & Vivian $\times$ Federica & 440 & $\mathrm{f} 1 / \mathrm{f} 1 ; \mathrm{f} 1 / \mathrm{f}_{\text {null }}$ & - \\
\hline 4. & Oro A & NM & Diamante OP & 440 & $\mathrm{fl} / \mathrm{f} 1 ; \mathrm{f} 1 / \mathrm{f}_{\text {null }}$ & $\mathrm{f} 1 / \mathrm{f1}[6][31]$ \\
\hline 5. & Ambra & M & Stark Red Gold $\times$ Mayfire & $440 ; 420 ; 410$ & $\mathrm{~F} / \mathrm{f}$ & - \\
\hline 6. & Bolero & M & Cresthaven $\times$ Flamecrest & $440 ; 410$ & $\mathrm{~F} / \mathrm{F} ; \mathrm{F} / \mathrm{f} 1 ; \mathrm{F} / \mathrm{f}_{\text {null }}$ & $\mathrm{F} / \mathrm{f} 1[6][31]$ \\
\hline 7. & Contender & M & $\begin{array}{c}\text { Wiblo } \times\{\text { Norman } \times[\text { Candor } \times \\
(\text { Summercrest } \times \text { Redhaven })]\}\end{array}$ & $440 ; 410$ & $\mathrm{~F} / \mathrm{F} ; \mathrm{F} / \mathrm{f} 1 ; \mathrm{F} / \mathrm{f}_{\text {null }}$ & $\mathrm{F} / \mathrm{F}[31]$ \\
\hline 8. & $\operatorname{Max} 7$ & M & - & $440 ; 420 ; 410$ & $F / f$ & - \\
\hline 9. & Big Top ${ }^{\circledast}$ & SS & - & 420 & $f / f_{\text {null }}$ & $\mathrm{f} / \mathrm{f} ; \mathrm{f} / \mathrm{f}_{\text {null }}[31]$ \\
\hline 10. & Alitop $^{\infty}$ & SS & $($ Flavortop $\times$ SnowQueen $) \times$ Big Top & $440 ; 410$ & $\mathrm{~F} / \mathrm{f}_{\text {null }}$ & - \\
\hline 11. & BO 96016015 & M & Contender $\times$ Ambra & $440 ; 420 ; 410$ & $\mathrm{~F} / \mathrm{f}$ & - \\
\hline 12. & BO 96016018 & M & Contender $\times$ Ambra & $440 ; 420 ; 410$ & $\mathrm{~F} / \mathrm{f}$ & - \\
\hline 13. & BO 96016023 & M & Contender $\times$ Ambra & $440 ; 420 ; 410$ & $\mathrm{~F} / \mathrm{f}$ & - \\
\hline 14. & BO 96016094 & M & Contender $\times$ Ambra & $440 ; 410$ & $\mathrm{~F} / \mathrm{F} ; \mathrm{F} / \mathrm{f} 1 ; \mathrm{F} / \mathrm{f}_{\text {null }}$ & - \\
\hline 15. & BO 96016136 & M & Contender $\times$ Ambra & $440 ; 410$ & $\mathrm{~F} / \mathrm{F} ; \mathrm{F} / \mathrm{f} 1 ; \mathrm{F} / \mathrm{f}_{\text {null }}$ & - \\
\hline 16. & BO 96016165 & M & Contender $\times$ Ambra & $440 ; 420 ; 410$ & $\mathrm{~F} / \mathrm{f}$ & - \\
\hline 17. & BO 96016208 & M & Contender $\times$ Ambra & $440 ; 420 ; 410$ & $F / f$ & - \\
\hline 18. & BO 96028059 & SS & Springred $\times$ Big Top & $440 ; 420 ; 410$ & $\mathrm{~F} / \mathrm{f}$ & - \\
\hline 19. & BO 02002002 & M & Ambra $\times$ Big Top & $440 ; 420 ; 410$ & $\mathrm{~F} / \mathrm{f}$ & - \\
\hline 20. & BO 02002003 & M & Ambra $\times$ Big Top & $440 ; 420 ; 410$ & $F / f$ & - \\
\hline 21. & BO 02002004 & M & Ambra $\times$ Big Top & $440 ; 420 ; 410$ & $\mathrm{~F} / \mathrm{f}$ & - \\
\hline 22. & BO 02002005 & M & Ambra $\times$ Big Top & $440 ; 420 ; 410$ & $\mathrm{~F} / \mathrm{f}$ & - \\
\hline 23. & BO 02002006 & M & Ambra $\times$ Big Top & 420 & $\mathrm{f} / \mathrm{f} ; \mathrm{f} / \mathrm{f}_{\text {null }}$ & - \\
\hline 24. & BO 02002008 & M & Ambra $\times$ Big Top & $440 ; 420 ; 410$ & $F / f$ & - \\
\hline 25. & BO 02002009 & M & Ambra $\times$ Big Top & $440 ; 420 ; 410$ & $\mathrm{~F} / \mathrm{f}$ & - \\
\hline 26. & BO 02002020 & M & Ambra $\times$ Big Top & 420 & $\mathrm{f} / \mathrm{f} ; \mathrm{f} / \mathrm{f}_{\text {null }}$ & - \\
\hline 27. & BO 02002023 & $\mathrm{M}$ & Ambra $\times$ Big Top & $440 ; 410$ & $\mathrm{~F} / \mathrm{f}_{\text {null }}$ & - \\
\hline 28. & BO 02002025 & M & Ambra $\times$ Big Top & 420 & $f / f ; f / f_{\text {null }}$ & - \\
\hline 29. & BO 02002026 & M & Ambra $\times$ Big Top & $440 ; 420 ; 410$ & $F / f$ & - \\
\hline 30. & BO 02002001 & SS & Ambra $\times$ Big Top & 420 & $\mathrm{f} / \mathrm{f} ; \mathrm{f} / \mathrm{f}_{\text {null }}$ & - \\
\hline 31. & BO 02002011 & SS & Ambra $\times$ Big Top & 420 & $\mathrm{f} / \mathrm{f} ; \mathrm{f} / \mathrm{f}_{\text {null }}$ & - \\
\hline 32. & BO 02002012 & SS & Ambra $\times$ Big Top & $440 ; 420 ; 410$ & $\mathrm{~F} / \mathrm{f}$ & - \\
\hline 33. & BO 02002014 & SS & Ambra $\times$ Big Top & $440 ; 420 ; 410$ & $F / f$ & - \\
\hline 34. & BO 02002015 & SS & Ambra $\times$ Big Top & $440 ; 420 ; 410$ & $\mathrm{~F} / \mathrm{f}$ & - \\
\hline 35. & BO 02002017 & SS & Ambra $\times$ Big Top & $440 ; 410$ & $\mathrm{~F} / \mathrm{f}_{\text {null }}$ & - \\
\hline 36. & BO 02002018 & SS & Ambra $\times$ Big Top & $440 ; 420 ; 410$ & $\mathrm{~F} / \mathrm{f}$ & - \\
\hline 37. & BO 02002019 & SS & Ambra $\times$ Big Top & 420 & $\mathrm{f} / \mathrm{f} ; \mathrm{f} / \mathrm{f}_{\text {null }}$ & - \\
\hline 38. & BO 02002021 & SS & Ambra $\times$ Big Top & $440 ; 410$ & $\mathrm{~F} / \mathrm{f}_{\text {null }}$ & - \\
\hline 39. & BO 02002024 & SS & Ambra $\times$ Big Top & $440 ; 420 ; 410$ & $\mathrm{~F} / \mathrm{f}$ & - \\
\hline
\end{tabular}




\section{Continued}

\begin{tabular}{|c|c|c|c|c|c|c|}
\hline 40. & BO 02002013 & NC & Ambra $\times$ Big Top & 420 & $\mathrm{f} / \mathrm{f} ; \mathrm{f} / \mathrm{f}_{\text {null }}$ & - \\
\hline 41. & BO 02002022 & NC & Ambra $\times$ Big Top & 420 & $\mathrm{f} / \mathrm{f} ; \mathrm{f} / \mathrm{f}_{\text {null }}$ & - \\
\hline 42. & BO 02004001 & M & Max $7 \times$ Big Top & $440 ; 420 ; 410$ & $\mathrm{~F} / \mathrm{f}$ & - \\
\hline 43. & BO 02004004 & M & Max $7 \times$ Big Top & $440 ; 420 ; 410$ & $\mathrm{~F} / \mathrm{f}$ & - \\
\hline 44. & BO 02004006 & M & Max $7 \times$ Big Top & $440 ; 420 ; 410$ & $F / f$ & - \\
\hline 45. & BO 02004008 & M & Max $7 \times$ Big Top & $440 ; 410$ & $\mathrm{~F} / \mathrm{f}_{\text {null }}$ & - \\
\hline 46. & BO 02004015 & M & Max $7 \times$ Big Top & 420 & $\mathrm{f} / \mathrm{f} ; \mathrm{f} / \mathrm{f}_{\text {null }}$ & - \\
\hline 47. & BO 02004016 & M & Max $7 \times$ Big Top & $440 ; 420 ; 410$ & $\mathrm{~F} / \mathrm{f}$ & - \\
\hline 48. & BO 02004017 & M & Max $7 \times$ Big Top & $440 ; 420 ; 410$ & $\mathrm{~F} / \mathrm{f}$ & - \\
\hline 49. & BO 02004018 & M & Max $7 \times$ Big Top & 420 & $f / f ; f / f_{\text {null }}$ & - \\
\hline 50. & BO 02004024 & M & Max $7 \times$ Big Top & $440 ; 410$ & $\mathrm{~F} / \mathrm{f}_{\text {null }}$ & - \\
\hline 51. & BO 02004002 & SS & Max $7 \times$ Big Top & $440 ; 410$ & $\mathrm{~F} / \mathrm{f}_{\text {null }}$ & - \\
\hline 52. & BO 02004013 & SS & Max $7 \times$ Big Top & $440 ; 410$ & $\mathrm{~F} / \mathrm{f}_{\text {null }}$ & - \\
\hline 53. & BO 02004014 & SS & Max $7 \times$ Big Top & 420 & $\mathrm{f} / \mathrm{f} ; \mathrm{f} / \mathrm{f}_{\text {null }}$ & - \\
\hline 54. & BO 02004019 & SS & Max $7 \times$ Big Top & $440 ; 420 ; 410$ & $\mathrm{~F} / \mathrm{f}$ & - \\
\hline 55. & BO 02004021 & SS & Max $7 \times$ Big Top & 420 & $f / f ; f / f_{\text {null }}$ & - \\
\hline 56. & BO 02004022 & SS & Max $7 \times$ Big Top & 420 & $\mathrm{f} / \mathrm{f} ; \mathrm{f} / \mathrm{f}_{\text {null }}$ & - \\
\hline 57. & BO 02004023 & SS & Max $7 \times$ Big Top & $440 ; 420 ; 410$ & $\mathrm{~F} / \mathrm{f}$ & - \\
\hline 58. & BO 02004025 & SS & Max $7 \times$ Big Top & $440 ; 410$ & $\mathrm{~F} / \mathrm{f}_{\text {null }}$ & - \\
\hline 59. & BO 02004027 & SS & Max $7 \times$ Big Top & 420 & $f / f ; f / f_{\text {null }}$ & - \\
\hline 60. & BO 02004026 & M & Max $7 \times$ Big Top & 420 & $f / f ; f / f_{\text {null }}$ & - \\
\hline 61. & BO 02004003 & NC & Max $7 \times$ Big Top & 420 & $f / f ; f / f_{\text {null }}$ & - \\
\hline 62. & BO 02004005 & NC & Max $7 \times$ Big Top & 420 & $f / f ; f / f_{\text {null }}$ & - \\
\hline 63. & BO 02004007 & $\mathrm{NC}$ & Max $7 \times$ Big Top & $440 ; 420 ; 410$ & $F / f$ & - \\
\hline 64. & BO 02004009 & NC & Max $7 \times$ Big Top & $440 ; 410$ & $\mathrm{~F} / \mathrm{f}_{\text {null }}$ & - \\
\hline 65. & BO 02004010 & NC & Max $7 \times$ Big Top & 420 & $f / f ; f / f_{\text {null }}$ & - \\
\hline 66. & BO 02004011 & NC & Max $7 \times$ Big Top & 420 & $\mathrm{f} / \mathrm{f} ; \mathrm{f} / \mathrm{f}_{\text {null }}$ & - \\
\hline 67. & BO 02004012 & NC & Max $7 \times$ Big Top & 420 & $\mathrm{f} / \mathrm{f} ; \mathrm{f} / \mathrm{f}_{\text {null }}$ & - \\
\hline 68. & BO 02004020 & NC & Max $7 \times$ Big Top & 420 & $f / f ; f / f_{\text {null }}$ & - \\
\hline 69. & Glohaven & M & SH $20 \times$ Kalhaven & $440 ; 410$ & $\mathrm{~F} / \mathrm{F} ; \mathrm{F} / \mathrm{f} 1 ; \mathrm{F} / \mathrm{f}_{\text {null }}$ & - \\
\hline 70. & Springbelle & M & - & $440 ; 410$ & $\mathrm{~F} / \mathrm{F} ; \mathrm{F} / \mathrm{f} 1 ; \mathrm{F} / \mathrm{f}_{\text {null }}$ & - \\
\hline 71. & Springcrest & M & FV $89-14 \times$ Springtime & $440 ; 410$ & $\mathrm{~F} / \mathrm{F} ; \mathrm{F} / \mathrm{f} 1 ; \mathrm{F} / \mathrm{f}_{\text {null }}$ & $\mathrm{F} / \mathrm{F}, \mathrm{F} / \mathrm{f} 1, \mathrm{~F} / \mathrm{f}_{\text {null }}[31]$ \\
\hline 72. & Maycrest & M & Springcrest mutation & $440 ; 410$ & $\mathrm{~F} / \mathrm{F} ; \mathrm{F} / \mathrm{f} 1 ; \mathrm{F} / \mathrm{f}_{\text {null }}$ & $\mathrm{F} / \mathrm{F}, \mathrm{F} / \mathrm{f} 1, \mathrm{~F} / \mathrm{f}_{\text {null }}[31]$ \\
\hline 73. & Springred & M & Summer Grand OP & $440 ; 410$ & $\mathrm{~F} / \mathrm{F} ; \mathrm{F} / \mathrm{f} 1 ; \mathrm{F} / \mathrm{f}_{\text {null }}$ & - \\
\hline 74. & $7-28$ & $\mathrm{SH}$ & Koyohakuto $\times$ Okubo & $440 ; 420 ; 410$ & $\mathrm{~F} / \mathrm{f}$ & - \\
\hline 75. & D $41-62$ & SH & - & 420 & $f / f, f / f_{\text {null }}$ & - \\
\hline 76. & Ghiaccio & $\mathrm{SH}$ & $\begin{array}{c}193 \text { Q XXVII } 111 \text { (Yumyeong } \\
\text { self-pollination) }\end{array}$ & 420 & $\mathrm{f} / \mathrm{f}, \mathrm{f} / \mathrm{f}_{\text {null }}$ & - \\
\hline 77. & Yumyeong & SH & Yamato-Wase $\times$ Nunome Wase & 420 & $f / f, f / f_{\text {null }}$ & $\mathrm{f} / \mathrm{f}[31]$ \\
\hline 78. & Helena Cling & SS & - & 420 & $f / f, f / f_{\text {null }}$ & - \\
\hline 79. & BO 96013046 & SS & Bolero $\times$ Rich Lady & $440 ; 420 ; 410$ & $\mathrm{~F} / \mathrm{f}$ & - \\
\hline 80. & Honey Gold & SS & - & $440 ; 420 ; 410$ & $\mathrm{~F} / \mathrm{f}$ & - \\
\hline 81. & Ruby Rich & SS & - & $440 ; 420 ; 410$ & $\mathrm{~F} / \mathrm{f}$ & $\mathrm{F} / \mathrm{f}[31]$ \\
\hline 82. & Vista Rich & SS & Rich Lady OP & $440 ; 420 ; 410$ & $F / f$ & - \\
\hline 83. & P LOV $31 \mathrm{~N}$ & - & Lovell OP & 440 & f1 & - \\
\hline 84. & P RRL $11 \mathrm{~N}$ & - & Rutgers Red Leaf OP & $440 ; 410$ & $\mathrm{~F}$ & - \\
\hline 85. & P VIN $11 \mathrm{~N}$ & - & Vineland OP & 440 & f1 & - \\
\hline
\end{tabular}


Table 2. Climate and weather conditions recorded in the orchard during the time period of fruit growing season. n. d.: not determined.

\begin{tabular}{cccc}
\hline \multirow{2}{*}{ Month } & \multicolumn{3}{c}{ Climate and Weather Conditions in the Orchard } \\
\cline { 2 - 4 } & Average temperature $\left({ }^{\circ} \mathrm{C}\right)$ & Rainfall $(\mathrm{mm})$ & $\begin{array}{c}\text { Relative humidity } \\
(\%)\end{array}$ \\
\hline March & 16.9 & 101 & 73.9 \\
April & 20.1 & 19.0 & 65.3 \\
May & 22.8 & 32.2 & 60.4 \\
June & 26.4 & 112 & 64.4 \\
July & 23.8 & n. d. & 41.9 \\
August & & 19.6 & 54.1 \\
\hline
\end{tabular}

cultivar by visual assessment of the skin ground color [2] [25], and sensory determination of approximate firmness.

Assessment of the latter parameter by human inspectors' grading is coherent with instrumented measurements [26], and represents a non-destructive method capable to yield information on the time course of fruit texture evolution.

Discrimination between M and SS phenotypes was based upon sensory scoring of flesh texture changes during $4 \mathrm{~d}$ of postharvest at room temperature. Due to stunted growth and low fruit set, in a few $F_{1}$ offsprings from selected crosses, fruit were not phenotypically classifiable; haploids also had stunted growth and did not produce fruit at all, so the fruit flesh phenotype remained unascertained.

\subsection{Extraction of Genomic DNA}

Genomic DNA from young leaves was used as template for the analysis of the amplification profiles based on major InDel polymorphisms in Intron 3 of the $P p$-endoPG sequence [5] [6], and for CAPS analysis [27] based on the $\mathrm{SNP}_{348}$ of the $P$-endoPG $G^{B T}$ variant of $\mathrm{F}^{\mathrm{a}}$-Ppa006839 $m[6]$.

Extraction was conducted according to Geuna et al. [28]. Frozen leaf samples (100 mg fresh weight) were powdered in liquid $\mathrm{N}_{2}$ by a mortar and a pestle and mixed with $600 \mu \mathrm{L}$ of preheated $\left(65^{\circ} \mathrm{C}\right)$ extraction buffer $[0.2 \mathrm{M}$ Tris (tris hydroxymethyl aminomethane)- $\mathrm{HCl}, \mathrm{pH} 8.5,10 \mathrm{mM}$ EDTA (ethylenediaminetetraacetic acid), $0.3 \mathrm{M} \mathrm{LiCl}, 1.5 \%$ (v/v) SDS (sodium dodecyl sulphate), $1 \%$ (w/v) Nonidet $^{\mathrm{tm}} \mathrm{P}-40,1 \mathrm{mM}$ DTT (1,4-dithiothreitol)]. Samples were incubated at $65^{\circ} \mathrm{C}$ for $20 \mathrm{~min}$ and centrifuged $\left(15,000 \mathrm{~g}, 4^{\circ} \mathrm{C}, 20 \mathrm{~min}\right)$. The aqueous solution was extracted in one volume of (in sequence) phenol, phenol/chloroform/isoamyl alcohol (25/24/1 by volume), and chloroform, with centrifugation $\left(15,000 \mathrm{~g}, 4^{\circ} \mathrm{C}, 20\right.$ $\mathrm{min}$ ) after each passage. DNA was precipitated by adding 0.1 volume of $3 \mathrm{M}$ $\mathrm{Na}$-acetate, pH 5.2 plus 0.6 volume of 2 -propanol, followed by incubation at $4^{\circ} \mathrm{C}$ for $1 \mathrm{~h}$ and centrifugation $\left(15,000 \mathrm{~g}, 4^{\circ} \mathrm{C}, 30 \mathrm{~min}\right)$. Pellets were washed with 1 $\mathrm{mL}$ of $70 \%(\mathrm{v} / \mathrm{v})$ ethanol, air-dried and resuspended in $100 \mu \mathrm{L}$ of double-distilled $\mathrm{H}_{2} \mathrm{O}$. Three microliters of these extracts were analyzed for quality and yield on $1 \%(\mathrm{w} / \mathrm{v})$ agarose gel in $1 \times$ TBE buffer ( $89 \mathrm{mM}$ Tris-Borate, $2 \mathrm{mM} \mathrm{Na}_{2}$-EDTA, $\mathrm{pH} 8.2$ plus $1 \mu \mathrm{g} \mathrm{mL} \mathrm{m}^{-1}$ ethidium bromide; low ionic strength), also used as elec- 
trophoresis buffer. Lambda DNA/Hind III genomic DNA and $1 \mathrm{~kb}$ DNA Plus Ladder (Invitrogen Life Technologies, Monza, Italy) were run as standards of concentration and size. Nucleic acids were visualized under UV light. The quantified DNA was treated with $10 \mathrm{mg} \mathrm{mL}^{-1}$ RNase A (Invitrogen Life Technologies) at $37^{\circ} \mathrm{C}$ for $1 \mathrm{~h}$ to remove any RNA contamination and precipitated as described above.

\subsection{InDel Analysis}

A $\sim 40$ bp sequence of the $P p$-endoPG gene region encompassing a few bases of Exon 3 and a wide sequence of Intron 3 comprising the major InDels [6] was amplified with proper primers ( $P$ p-endoPG_InDel $l_{F o r}$ : 5'-GTGCCCTGGTCAGGTAAG-3'; $P p$-endoPG_InDel ${ }_{\text {Rer }}$ : 5'-GGCTAAGCTACGATGAAGTC-3') in a MyCycler Thermal Cycler (Bio-Rad Laboratories Srl, Segrate, Italy). The PCR mix contained 20 ng genomic DNA, $0.3 \mathrm{mM}$ dNTPs (deoxynucleotides), $0.3 \mu \mathrm{M}$ of each primer, $1 \times$ GoTaq Reaction Buffer ${ }^{\oplus}, 1 \mathrm{U}$ Go Taq ${ }^{\oplus}$ DNA Polymerase (Promega, Segrate, Italy) and double-distilled $\mathrm{H}_{2} \mathrm{O}$ to a final volume of $25 \mu \mathrm{L}$. The conditions of PCR reaction were: one denaturation cycle $\left(94^{\circ} \mathrm{C}, 4 \mathrm{~min}\right), 35$ cycles comprehensive of denaturation $\left(94^{\circ} \mathrm{C}, 30 \mathrm{~s}\right)$, annealing $\left(62^{\circ} \mathrm{C}, 30 \mathrm{~s}\right)$ and extension phases $\left(72^{\circ} \mathrm{C}, 45 \mathrm{~s}\right)$ and one final extension cycle $\left(72^{\circ} \mathrm{C}, 5 \mathrm{~min}\right)$.

The amplification products were separated on $3 \%(\mathrm{w} / \mathrm{v})$ agarose gel and visualized (DirectLoad ${ }^{\text {tw }} 50$ bp DNA Step Ladder; Sigma-Aldrich) with ethidium bromide under UV light.

\subsection{CAPS Analysis}

Primer pairs ( $P$ p-endoPG $G_{F o r}$ 5'-ATGGCGAACCGTAGAAGCCTCT-3'; $P p$-endoPG ${ }^{B T}{ }_{R e r}$ 5'-CCACAAGCAACGCCTTCTATCC-3') were designed to amplify the 1-972 bp region of $P$ p-endoPG including the $\mathrm{SNP}_{348}$ of interest [6], which determined the polymorphic restriction site. Amplification was conducted as described above for InDel analysis and was followed by digestion of the polymorphic fragments [ $1 \mu \mathrm{g}$ of amplification products, $5 \mathrm{U}$ of $B s t \mathrm{XI}$ restriction enzyme (Promega), $\left.37^{\circ} \mathrm{C}, 90 \mathrm{~min}\right]$. The reaction products, separated on $3 \%$ $(\mathrm{w} / \mathrm{v})$ agarose gels, were visualized by ethidium bromide (TrackIt ${ }^{\mathrm{tm}} 1 \mathrm{~Kb}$ Plus DNA Ladder; Invitrogen).

\section{Results}

\subsection{InDel Analysis of Different Peach Accessions}

Amplification of the cited genomic sequence of $P p$-endoPG including the InDels of interest confirmed the presence of two amplicons of apparent length of $\sim 440$ bp and $\sim 410$ bp in Bolero, consistent with the expected lengths of $437 \mathrm{bp}$ and 403 bp for $\mathrm{F}^{\mathrm{a}}-P p a 006839 m\left(P p\right.$-endoP $\left.G^{m}\right)$ and $\mathrm{F}^{\mathrm{b}}-P p a 006857 m$ (Pp-endoPG_M) [5] [6].

The M cultivars Contender, Maycrest, Springbelle, Springcrest, Springred, Glohaven, plus two (BO 96016136 and BO 96016094) out of the seven offsprings 
from the cross Contender $(\mathrm{M}) \times$ Ambra $(\mathrm{M})$ showed a Bolero-like amplification pattern with two fragments. In Ambra and in five offsprings from Contender $\times$ Ambra (BO 96016015, BO 96016018, BO 96016023, BO 96016165, and BO 96016208) an additional amplicon of $\sim 420$ bp was observed (Figure 1).

Figure 2 shows the results obtained in NM, SH, and SS accessions. In the NM Oro A, Andross [29], Ionia, and BO 82010554 (offspring of NM Jungerman $\times$ NM Loadel), only one amplicon of $\sim 440$ bp was retrieved. In the $\mathrm{SH}$ accessions Yumyeong, Ghiaccio, Helena Cling, and D 41-62, as well as in SS Big Top, amplification generated only one fragment of $\sim 420 \mathrm{bp}$, confirming the presence of the $P p$-endoPG $G^{S H}$-or $P p$-endoPG $G^{B T}$-like variants of $\mathrm{F}^{\mathrm{a}}$ - $P$ pa006839m, respectively [6].

The amplification pattern of SS Alitop was similar to that of Bolero. SH 7-28 and the SS Honey Gold, Ruby Rich, Vista Rich, BO 96028059 ( $F_{1}$ from M Springred $\times$ SS Big Top) and BO $96013046\left(F_{1}\right.$ from M Bolero $\times$ SS Rich Lady) yielded three amplicons ( $\sim 40 \mathrm{bp}, \sim 420 \mathrm{bp}$, and $\sim 410 \mathrm{bp}$ ). The two haploids P VIN $11 \mathrm{~N}$ and P LOV $31 \mathrm{~N}$ yielded amplification patterns similar to that of Oro A (a single fragment of $\sim 440 \mathrm{bp}$ ), whereas the pattern of P RRL $11 \mathrm{~N}$ was similar to that of Bolero (two fragments of $\sim 440 \mathrm{bp}$ and $\sim 410 \mathrm{bp}$; Figure 3).

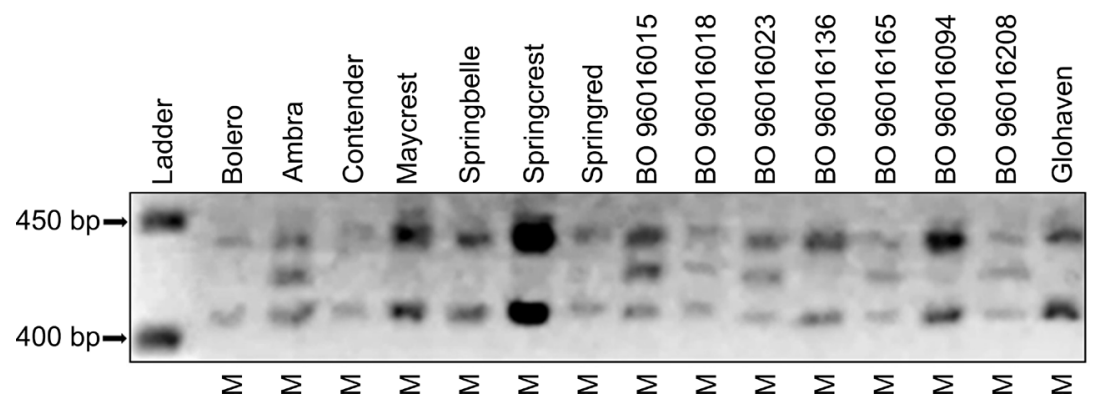

Figure 1. InDel analysis of $P p$-endoPG in accessions with $M$ fruit flesh texture. Positions and lengths of DNA markers (DirectLoad ${ }^{\mathrm{T}} 50 \mathrm{bp}$ DNA Step Ladder; Sigma-Aldrich) are shown on the left. Twenty micrograms DNA were loaded per lane; the amplicons were separated on $3 \%(\mathrm{w} / \mathrm{v})$ agarose gels. One representative gel from three independent experiments.

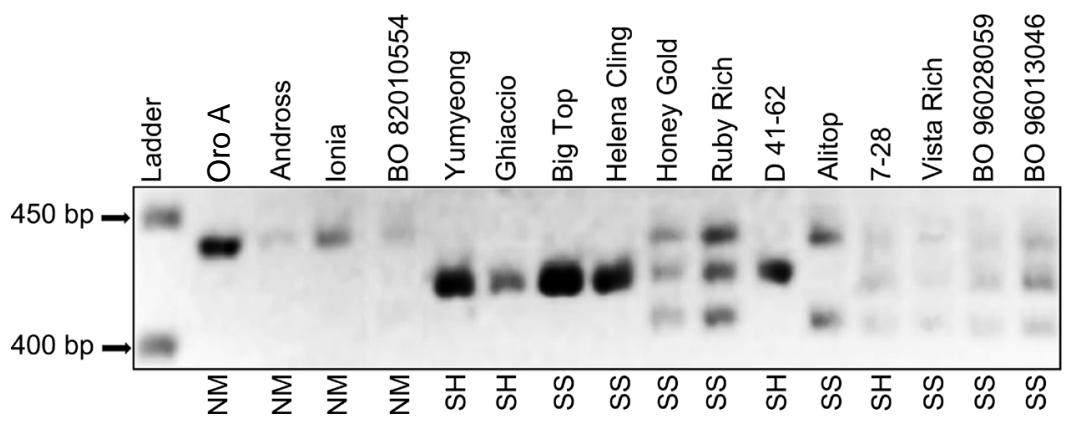

Figure 2. InDel analysis of $P p$-endoPG in accessions with NM, SH or SS fruit flesh texture. Positions and lengths of DNA markers (DirectLoad ${ }^{\mathrm{ms}} 50$ bp DNA Step Ladder) are shown on the left. Twenty micrograms DNA were loaded per lane; the amplicons were separated on $3 \%(\mathrm{w} / \mathrm{v})$ agarose gels. One representative gel from three independent experiments. 


\subsection{Ambra $\times$ Big Top and Max $7 \times$ Big Top Crosses: InDel Analysis of F1 Offsprings}

Figure 4 shows the amplification patterns obtained in the M Ambra and SS Big Top parents and in $23 \mathrm{~F}_{1}$ seedlings from their cross (from BO 02002001 to BO 02002006, BO 02002008, BO 02002009, from BO 02002020 to BO 02002026, from BO 02002011 to BO 02002015, from BO 02002017 to BO 02002019). The amplification profiles were similar to that of the Big Top parent (one amplicon of $\sim 420 \mathrm{bp}$ ) for eight of them, and to that of the Ambra parent (three amplicons of $\sim 440 \mathrm{bp}, \sim 420 \mathrm{bp}$, and $\sim 410 \mathrm{bp}$ ) for 12 . Three accessions showed the same pattern as Bolero ( $\sim 40$ bp and $\sim 410$ bp; compare to Figure 1 ).

Figure 5 shows the amplification profiles obtained in the M Max 7 and SS Big Top parents and in $27 \mathrm{~F}_{1}$ seedlings from their cross (from BO 02004001 to BO 02004027). In Max 7, as well as in eight offsprings, amplification yielded three fragments ( 440 bp, $\sim 420 \mathrm{bp}$, and $\sim 410 \mathrm{bp}$ ). Amplification profiles similar to that of Big Top (one fragment of $\sim 420 \mathrm{bp}$ ) were found in 13 seedlings, whereas six seedlings yielded Bolero-like ( $\sim 40 \mathrm{bp}$ and $\sim 410 \mathrm{bp}$ fragments) patterns (compare to Figure 1).

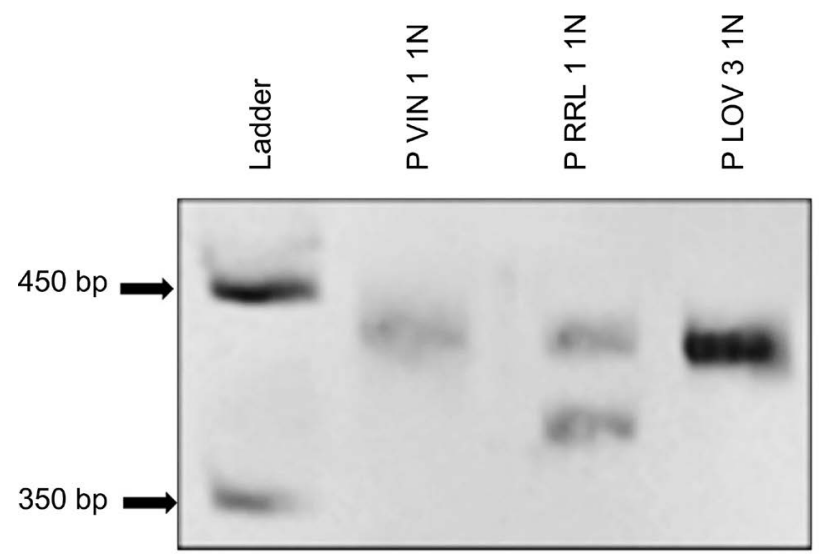

Figure 3. InDel analysis of $P p$-endoPG in three haploid accessions. Positions and lengths of DNA markers (50 bp DNA Step Ladder; Sigma-Aldrich) are shown on the left. Twenty micrograms DNA were loaded per lane; the amplicons were separated on $3 \%(\mathrm{w} / \mathrm{v})$ agarose gel. One representative gel from three independent experiments.

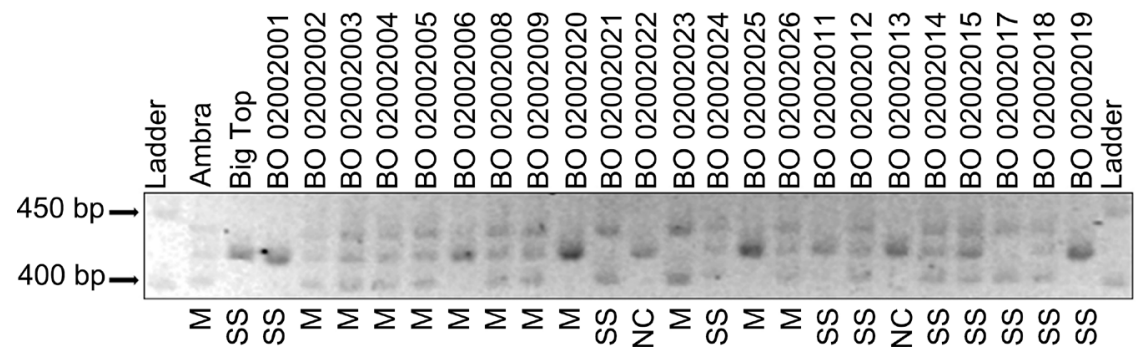

Figure 4. InDel analysis of $P p$-endoPG in M Ambra, SS Big Top and in $23 \mathrm{~F}_{1}$ seedlings. Positions and lengths of DNA markers (DirectLoad ${ }^{\mathrm{Ts}} 50 \mathrm{bp}$ DNA Step Ladder) are shown. NC, not classifiable. Twenty micrograms DNA were loaded per lane; amplicons were separated on $3 \%(\mathrm{w} / \mathrm{v})$ agarose gel. One representative gel from three independent experiments. 


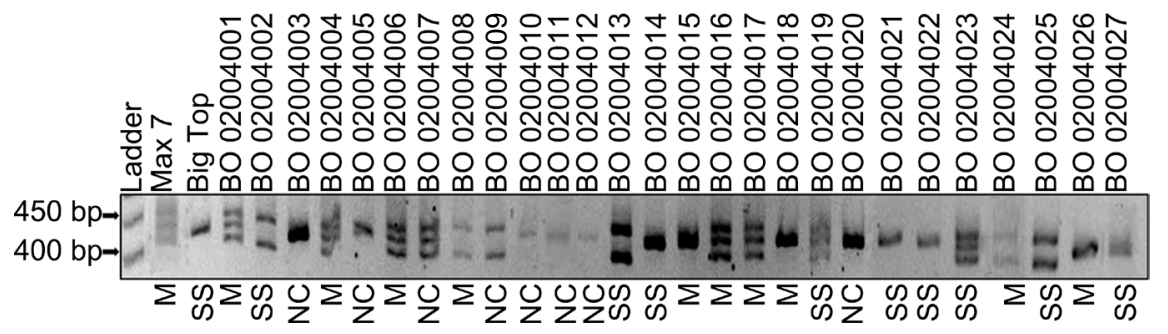

Figure 5. InDel analysis of $P p$-endoPG in M Max 7, SS Big Top, and in $27 \mathrm{~F}_{1}$ seedlings. Positions and lengths of DNA markers (DirectLoad ${ }^{\mathrm{mm}} 50$ bp DNA Step Ladder) are shown on the left. NC, not classifiable. Twenty micrograms DNA were loaded per lane; amplicons were separated on $3 \%(w / v)$ agarose gel. One representative gel from three independent experiments.

\subsection{Cleaved Amplified Polymorphic Sequence (CAPS) Analysis}

In the $P p$-endoPG $G^{B T}$ variant of $\mathrm{F}^{\mathrm{a}}-P$ pa006839m present in Big Top, a peculiar, silent $\mathrm{SNP}_{348}$ in Exon 1 originates a polymorphic sequence recognized by the BstXI restriction enzyme (Figure 6(b)), suitable for distinguishing between the $P p$-endoPG ${ }^{B T}$ and $P p$-endoPG ${ }^{S H}$ variants of $\mathrm{F}^{\mathrm{a}}-P$ pa006839m $\left(P p\right.$-endoPG $\left.{ }^{m}\right)$ [6].

The $\mathrm{SNP}_{348}$ was exploited to broaden CAPS analysis to a few additional cultivars/accessions phenotypically scored as SS (Alitop, Helena Cling, Honey Gold, Ruby Rich, Vista Rich, BO 96028059, BO 96013046) or SH (D 41-62, 7-28) (Table 1). BstXI confirmed to be ineffective in Oro A and in Bolero, as it was in all the accessions scored as SH. Concerning the accessions scored as SS, Helena Cling showed, like Big Top, two digestion fragments; Honey Gold, Ruby Rich, Vista Rich, BO 96028059, and BO 96013046 showed two Big Top-like restriction fragments plus an undigested one, whereas BstXI was ineffective in Alitop (Figure 6(c)).

\section{Discussion}

The $\mathrm{F}$ allele at the endoPG locus on peach chromosome 4 contains two gene sequences, i.e. $\mathrm{F}^{\mathrm{a}}$ (Ppa006839m) and $\mathrm{F}^{\mathrm{b}}$ (Ppa006857m), at short distance (32-34 $\mathrm{kbp}$ ) from each other. Mutations and deletions of these genes determine several allelic variants: $F$, resulting from $F^{a}$ plus $F^{b} ; f$, resulting from mutation of $F^{a}$ plus complete deletion of $F^{b} ; f 1$, resulting from $F^{a}$ plus complete deletion of $F^{b}$; $f_{\text {null }}$, resulting from deep mutation or complete deletion of both $\mathrm{F}^{\mathrm{a}}$ and $\mathrm{F}^{\mathrm{b}}$. The different alleles $\mathrm{F}, \mathrm{f}, \mathrm{f1}, \mathrm{f}_{\text {null }}$ at the endoPG locus contribute to the fruit phenotype for stone adhesion and flesh texture [4] [18]. In particular, it has been recently suggested that $\mathrm{F}^{\mathrm{a}}$-Ppa006839m plays a driving role in the determination of the Melting/Non Melting trait, whereas $\mathrm{F}^{\mathrm{b}}$-Ppa006857m seems involved in the determination of the Clingstone/Freestone trait, although it has been speculated that $\mathrm{F}^{\mathrm{b}}$-Ppa006857m could exert a pleiotropic effect on flesh melting through a negative feedback control on the transcription of $\mathrm{F}^{\mathrm{a}}$-Ppa006839m [23].

From reference peach genotypes, peculiar endoPG sequences have been isolated. In particular, in NM Oro A has been retrieved a single sequence $\left(P p\right.$-endoP $\left.G^{m}\right)$ coincident with $P$ pa006839m, that does not present any deletion 


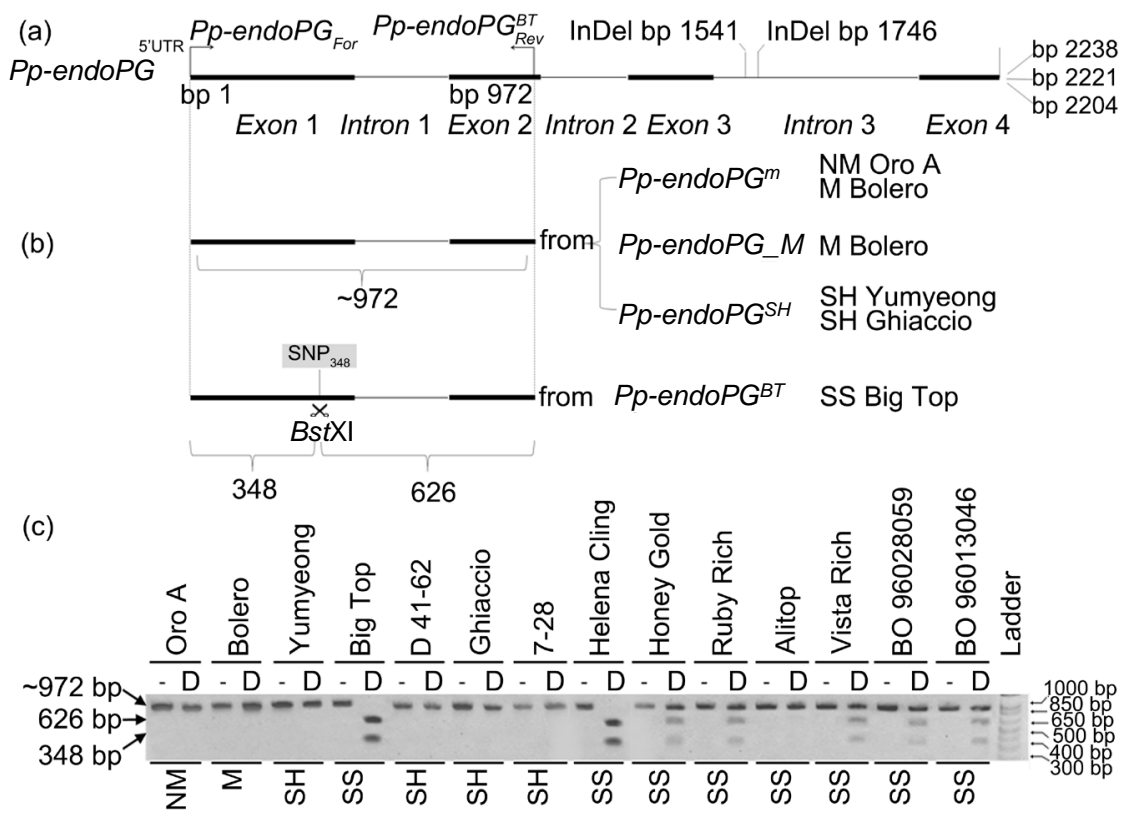

Figure 6. CAPS analysis exploiting the $\mathrm{SNP}_{348}$ of the $P p$-endoPG ${ }^{B T}$ variant of $\mathrm{F}^{\mathrm{a}}-P$ pa006839m. (a) Schematic representation of the structure of the $P p$-endoPG gene. Exons and introns are indicated by black solid bars and by solid lines, respectively; positions of the considered InDels of Intron 3 are also indicated. Arrows and vertical dotted lines define the region (1-972 bp) amplified by the primers used. (b) Lengths ( 972 bp) of the amplicons obtained from the $\mathrm{F}^{\mathrm{a}}$-Ppa006839m variants of: NM Oro A and M Bolero $\left(P p\right.$-endoP $\left.G^{m}\right)$, SH Yumyeong and SH Ghiaccio $\left(P p\right.$-endoPG $\left.G^{S H}\right)$, and SS Big Top $\left(P p\right.$-endoPG $\left.G^{B T}\right)$; position of the peculiar $\mathrm{SNP}_{348}$ of the $P$-endoPG $G^{B T}$ variant and predicted lengths ( $348 \mathrm{bp}$ and $626 \mathrm{bp}$ ) of the fragments obtainable by BstXI digestion (scissors symbol) are also indicated (modified from [6]). The $P p$-endoPG_M amplicon from $\mathrm{F}^{\mathrm{b}}$-Ppa006857m of Bolero is also reported. (c) Restriction patterns obtained in different accessions before (-) and after (D) digestion with BstXI. Positions and lengths of DNA markers (1 Kb Plus DNA Ladder, Invitrogen) are shown on the right. Expected lengths (bp) of the undigested amplicons and of the products of BstXI digestion are shown on the left. Twenty micrograms DNA were loaded per lane; $3 \%(w / v)$ agarose. One representative gel from three independent experiments.

in Intron 3, as reported also for the $\mathrm{F}^{\mathrm{a}}$ and $\mathrm{f} 1$ endoPG selected sequences. The allelic variants $\left(P p\right.$-endoP $\left.G^{B T / S H}\right)$ of $\mathrm{F}^{\mathrm{a}}$ - $P$ pa006839m, isolated from SS Big Top and SH Yumyeong and SH Ghiaccio, present a specific 17-bp deletion in Intron 3, apparently coincident with the deletion of the $\mathrm{f}$ sequence. In $\mathrm{M}$ Bolero has been isolated a sequence ( $P$ p-endoPG_M coincident with $\mathrm{F}^{\mathrm{b}}-P p a 006857 \mathrm{~m}$ and presenting two 17-bp deletions in Intron 3 as reported for $\mathrm{F}^{\mathrm{b}}$ [4] [5] [6]. Figure 7 summarizes the structure of the different alleles at the endoPG locus.

Genotype-specific Pp-endoPG polymorphisms (InDels and SNPs; [5] [6]) were exploited in the present work as tools to describe 85 peach accessions (Table 1). InDel analysis confirmed the co-segregation of $\mathrm{F}^{\mathrm{a}}-P p a 006839 \mathrm{~m}\left(P p\right.$-endoP $\left.G^{m}\right)$ and $\mathrm{F}^{\mathrm{b}}-P$ pa006857m (Pp-endoPG_M). In fact, the longest ( $\left.440 \mathrm{bp}\right)$ amplicon from $\mathrm{F}^{\mathrm{a}}$-Ppa006839m was always accompanied by the shortest ( 410 bp) one from $\mathrm{F}^{\mathrm{b}}-\mathrm{Ppa} 006857 \mathrm{~m}$, as indicated by the simultaneous presence of three amplicons in several accessions and of both amplicons in the haploid P RRL $11 \mathrm{~N}$ 


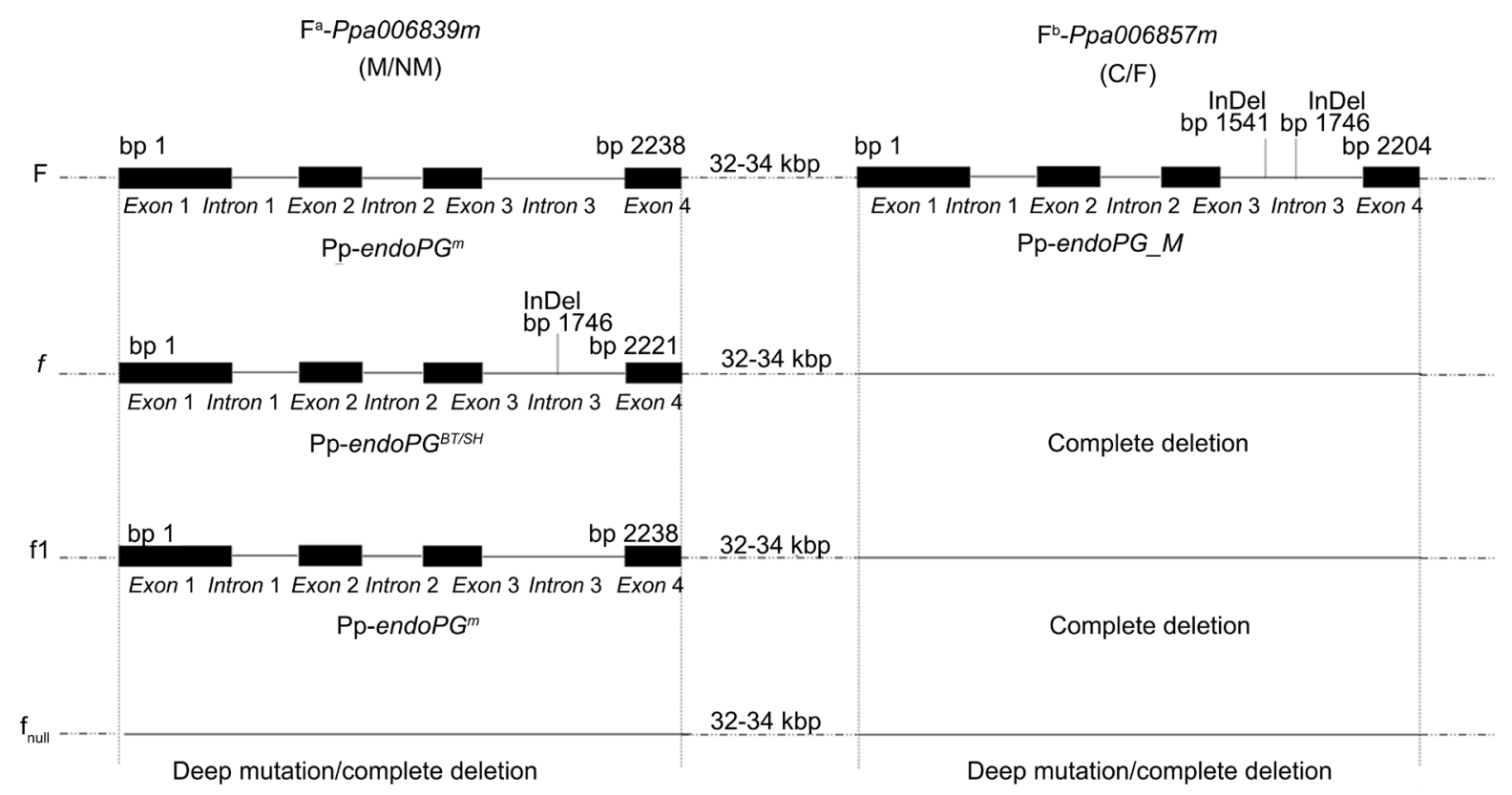

Figure 7. Schematic picture of the structure of the $P p$-endoPG locus with the different allelic variants and the discussed InDel mutations, as deduced from [4] [5] [6] [18]. C: Clingstone; F: Freestone. Exons are indicated by black solid bars and introns by solid lines.

(Figures 1-5). In the doubled haploid P LOV2 2N (from open pollination of Lovell) used for genome sequencing both the $\mathrm{F}^{\mathrm{a}}-\mathrm{Ppa006839m}$ and the $\mathrm{F}^{\mathrm{b}}$-Ppa006857m sequences are present [18] [23], while only the longest amplicon $(\sim 440 \mathrm{bp})$ was retrieved in the haploid P LOV3 $1 \mathrm{~N}$ (Figure 3 ) suggesting that Lovell is heterozygous (F/f1) at the endoPGlocus.

The individuated InDel polymorphisms in the endoPG sequences seem to distinguish the NM trait from the $\mathrm{M}$ one. In all the NM accessions (Oro A, Andross, Ionia, and BO 82010054) only the longest amplicon ( 440 bp; Figure 2) referable to a $\mathrm{F}^{\mathrm{a}}$-Ppa006839m-like variant is present. This result confirms what reported for NM phenotypes as determined by the presence of the $\mathrm{f} 1$ allele, in homozygosis (f1/f1) or in heterozygosis with $\mathrm{f}_{\text {null }}\left(\mathrm{f} 1 / \mathrm{f}_{\text {null }}\right)$ [23] [30] [31] (Figure 7; Table 1).

Most (31) of the 64 accessions scored as M or SS (all grouped in a general Melting class [6] [7]) were characterized by presence of all the three amplicons ( $\sim 40 \mathrm{bp}, \sim 420 \mathrm{bp}$ and $\sim 410 \mathrm{bp}$ ), referable respectively to $\mathrm{F}^{\mathrm{a}}-P p a 006839 \mathrm{~m}$ (no deletion), its $P$-endoPG $G^{B T / S H}$-like variants (one 17-bp deletion), and $\mathrm{F}^{\mathrm{b}}-P p a 006857 \mathrm{~m}$ (two 17-bp deletions). Eighteen accessions showed a pattern with the two amplicons of $\sim 440 \mathrm{bp}$ and $\sim 410 \mathrm{bp}$, and 15 showed only the amplicon of $\sim 420$ bp (Figures 1-4; Table 1). From these amplification profiles, it seems reasonable to deduce that the M and SS accessions can present all the three combinations of amplicons.

In particular, the InDel profiles of $M$ Contender, $M$ Maycrest and $M$ Springcrest (Figure 1; Table 1) appear consistent with their allelic combinations $\mathrm{F} / \mathrm{F}$ and $\mathrm{F} /$-reported in the literature [30] [31].

The InDel polymorphism, when scored in a cross progeny, appears useful to 
deduce the allelic combination at the endoPG locus of the parental genotypes, as in the case of Big Top. In fact, a few $\mathrm{F}_{1}$ individuals of the crosses Ambra $\times$ Big Top or Max $7 \times$ Big Top, as well as Alitop [(Flavortop $\times$ Snow Queen) $\times$ Big Top], lacked the amplicon of $\sim 420$ bp (Figure 2, Figure 4 and Figure 5). These results can only be explained by hypothesizing that Big Top is heterozygous at the endoPG locus for the presence of a "null" allele, in addition to the $f$ allele composed only by the Pp-endoPG ${ }^{\mathrm{BT}}$ variant of $\mathrm{F}^{\mathrm{a}}-\mathrm{Ppa} 006839 \mathrm{~m}$. The literature proposes for SS Big Top the allelic combinations $\mathrm{f} / \mathrm{f}$ or $\mathrm{f} / \mathrm{f}_{\text {null }}$ [30] [31]; our results seem to support the latter one (Figure 4 and Figure 5; Table 1).

The coherence of the allelic combinations at the endoPG locus inferred by the InDel analysis with, where available, those reported in the literature (Table 1) suggests that the InDel polymorphism may represent a tool for a simple genotyping of peach accessions. Nevertheless, this polymorphism does not allow to discriminate between the peculiar gene sequences individuated in SS or SH genotypes.

CAPS analysis exploiting the SNP individuated in Exon 1 of the endoPG sequence of SS Big Top integrates the InDel results allowing to distinguish between amplicons of $\sim 420$ bp derived from the $P p$-endoPG $G^{B T}$-like variant of $\mathrm{F}^{\mathrm{a}}$-Ppa006839m and the $P p$-endoPG ${ }^{S H}$-like one [6]. All the SS genotypes tested in CAPS analysis proved sensitive to BstXI producing upon cleavage two digestion fragments. In a few accessions, the contemporary presence of an undigested fragment indicated that their allelic asset was heterozygous (F/f; Figure 6(c) and Figure 2). For Ruby Rich, this asset confirms the functional genotype (F/f) proposed in the literature [30] [31] (Table 1). Lack of effect of BstXI in SS Alitop further confirms the inheritance of a possible 'null' $P p$-endoPG variant from the Big Top parent. Conversely, the SH genotypes tested were not sensitive to BstXI digestion (Figure 6(c)).

In the climacteric peach fruit the evolution of texture characteristics is regulated by ethylene. The $\mathrm{SH}$ trait ( $h d h d$ ) is related to absence of ethylene production for a mutation in the $P p-A C S 1$ gene and altered indole-3-acetic acid levels due to regulation of PpYUC11 [6] [32] [33] [34]. In SH 7-28, homozygous-recessive for the stony hard gene ( $h d h d$ ) [35], InDel analysis shows presence of the $\sim 420$ bp amplicon (Figure 2) attributable, by CAPS analysis, to a $P p$-endoPG $G^{S H}$-like sequence (Figure $6(\mathrm{c})$ ). The contemporary presence of the other two amplicons allows to assign this accession, as far as it concerns $P p$-endoPG , to the Stony Hard melting category ( $h d h d M$-) consistent to Haji et al. [36].

Therefore, it can be concluded that although CAPS analysis of the specific $P p$-endoPG $G^{B T / S H}$ variants seems to allow a preliminary distinction of SS from $\mathrm{SH}$ genotypes, conclusive phenotypic attribution of a specific accession will necessarily require the assessment of other activities like fruit ethylene production.

\section{Conclusions}

The two molecular markers (InDel and CAPS) based upon $P p$-endoPG poly- 
morphisms tested in the present work may represent useful tools for simple genotyping of peach accessions as far as it concerns the characteristics and different allelic combinations at the endoPG locus.

In particular, the use of the $P p$-endoPG InDel marker yields results consistent with the existing knowledge on the polymorphic structure of the endoPG locus in peach, and allows to individuate NM accessions. The CAPS marker developed on the basis of the peculiar $\mathrm{SNP}_{348}$ of SS Big Top integrates the results of InDel analysis by discriminating the $P p$-endoPG variants in $\mathrm{SS}$ and $\mathrm{SH}$ accessions.

Future development of the work may foresee the testing of a broader number of NM, as well as SS and SH accessions, in order to confirm the potential use of the described InDel and CAPS markers in Marker-Assisted Selection peach breeding programs.

\section{Acknowledgements}

This work was funded by the Italian Ministry of University and Research (MIUR) PRIN-COFIN 2006 grant number 2006078852, and by the MAS.PES Project (public-private breeding program supported by Italian growers' organizations and the University of Milan, Italy). The authors thank S. Foschi and M. Lama for their technical assistance in field operations.

\section{References}

[1] Bruhn, C.M. (1995) Consumer and Retailer Satisfaction with the Quality and Size of California Peaches and Nectarines. Journal of Food Quality, 18, 241-256. https://doi.org/10.1111/j.1745-4557.1995.tb00378.x

[2] Bassi, D. and Monet, R. (2008) 1. Botany and Taxonomy. In: Layne, D.R. and Bassi, D., Eds., The Peach: Botany, Production and Uses, CAB International, Wallingford, 1-36. https://doi.org/10.1079/9781845933869.0001

[3] Yoshida, M. (1976) Genetic Studies on the Fruit Quality of Peach Varieties. III. Texture and Keeping Quality. Bulletin of the Fruit Tree Research Station, 3, 1-16. (In Japanese with English Abstract)

[4] Peace, C.P., Crisosto, C.H. and Gradziel, T.M. (2005) Endopolygalacturonase: A Candidate Gene for Freestone and Melting Flesh in Peach. Molecular Breeding, 16, 21-31. https://doi.org/10.1007/s11032-005-0828-3

[5] Morgutti, S., Negrini, N., Nocito, F.F., Ghiani, A., Bassi, D. and Cocucci, M. (2006) Changes in Endopolygalacturonase Levels and Characterization of a Putative Endo- $P G$ Gene During Fruit Softening in Peach Genotypes with Nonmelting and Melting Flesh Fruit Phenotypes. New Phytologist, 171, 315-328. https://doi.org/10.1111/j.1469-8137.2006.01763.x

[6] Ghiani, A., Negrini, N., Morgutti, S., Baldin, F., Nocito, F.F., Spinardi, A., et al. (2011) Melting of "Big Top" Nectarine Fruit: Some Physiological, Biochemical, and Molecular Aspects. Journal of the American Society for Horticultural Science, 136, 61-68.

[7] Byrne, D.H., Raseira, M.B., Bassi, D., Piagnani, M.C., Gasic, K., Reighard, G.L., et al. (2012) Peach. In: Badenes, M.L. and Byrne, D.H., Eds., Fruit Breeding, Series Handbook of Plant Breeding 8, Springer, New York, 505-569.

https://doi.org/10.1007/978-1-4419-0763-9_14 
[8] Redgwell, R.J. and Fischer, M. (2002) 3. Fruit Texture, Cell Wall Metabolism and Consumer Perceptions. In: Knee, M., Ed., Fruit Quality and Its Biological Basis, Sheffield Academic Press, Sheffield, 46-88.

[9] Negi, P.S. and Kanda, A.K (2008) 8. Structural Deterioration of the Produce: The Breakdown of Cell Wall Components. In: Paliyath, G., Murr, D.P., Handa, A.K. and Lurie, S., Eds., Postharvest Biology and Technology of Fruits, Vegetables, and Flowers, Wiley-Blackwell, Ames, 162-194.

[10] Lester, D.R., Speirs, G., Orr, G. and Brady, C.J. (1994) Peach (Prunus persica) Endo-PG cDNA Isolation and mRNA Analysis in Melting and Non-Melting Peach Cultivars. Plant Physiology, 105, 225-231. https://doi.org/10.1104/pp.105.1.225

[11] Lester, D.R., Sherman, W.B. and Atwell, B.J. (1996) Endopolygalacturonase and the Melting Flesh (M) Locus in Peach. Journal of the American Society for Horticultural Science, 121, 231-235.

[12] Callahan, A.M., Scorza, R., Bassett, C., Nickerson, M. and Abeles, F.B. (2004) Deletions in an Endopolygalacturonase Gene Cluster Correlate with Non-Melting Flesh Texture in Peach. Functional Plant Biology, 31, 159-168. https://doi.org/10.1071/FP03131

[13] Peace, C.P., Callahan, A., Ogundiwin, E.A., Potter, D., Gradziel, T.M., Bliss, F.A., et al. (2007) Endopolygalacturonase Genotypic Variation in Prunus. In: Litz, R.E. and Scorza, R., Eds., International Symposium on Biotechnology of Temperate Fruit Crops and Tropical Species, Acta Horticulturae, 738, 639-646. https://doi.org/10.17660/actahortic.2007.738.83

[14] Zou, X., Shi, C., Austin, R.S., Merico, D., Munholland, S., Marsolais, F., et al. (2014) Genome-Wide Single Nucleotide Polymorphism and Insertion-Deletion Discovery through Next-Generation Sequencing of Reduced Representation Libraries in Common Bean. Molecular Breeding, 33, 769-778. https://doi.org/10.1007/s11032-013-9997-7

[15] Agarwal, M., Shrivastava, N. and Padh, H. (2008) Advances in Molecular Marker Techniques and their Applications in Plant Science. Plant Cell Reports, 27, 617-631. https://doi.org/10.1007/s00299-008-0507-z

[16] Chavez, D.J., Beckman, T.G., Werner, D.J. and Chaparro, J.X. (2014) Genetic Diversity in Peach (Prunus persica (L.) Batsch) at the University of Florida: Past, Present and Future. Tree Genetics \& Genomes, 10, 1399-1417.

https://doi.org/10.1007/s11295-014-0769-2

[17] Salazar, J.A., Ruiz, D., Campoy, J.A., Sánchez-Pérez, R., Crisosto, C.H., Martínez-García, P.J., et al. (2014) Quantitative Trait Loci (QTL) and Mendelian Trait Loci (MTL) Analysis in Prunus. A Breeding Perspective and Beyond. Plant Molecular Biology Reporter, 32, 1-18. https://doi.org/10.1007/s11105-013-0643-7

[18] Verde, I., Abbott, A.G., Scalabrin, S., Jung, S., Su, S., Marroni, F., et al. (2013) The High-Quality Draft Genome of Peach (Prunus persica) Identifies Unique Patterns of Genetic Diversity, Domestication and Genome Evolution. Nature Genetics, 45, 487-494. https://doi.org/10.1038/ng.2586

[19] Ahmad, R., Parfitt, D.E., Fass, J., Ogundiwin, E., Dhingra, A. and Crisosto, C.H. (2011) Whole Genome Sequencing of Peach (Prunus persica L.) for SNP Identification and Selection. BMC Genomics, 12, 569. https://doi.org/10.1186/1471-2164-12-569

[20] Verde, I., Bassil, N., Scalabrin, S., Gilmore, B., Lawley, C.T., Gasic, K., et al. (2012) Development and Evaluation of a 9K SNP Array for Peach by Internationally Coordinated SNP Detection and Validation in Breeding Germplasm. PLoS ONE, 7, e35668. 
https://doi.org/10.1371/annotation/33f1ba92-c304-4757-91aa-555de64a0768

[21] Frett, T.J., Reighard, G.L., Okie, W.R. and Gasic, K. (2014) Mapping Quantitative Trait Loci Associated with Blush in Peach (Prunus persica (L.) Batsch). Tree Genetics \& Genomes, 10, 367-381. https://doi.org/10.1007/s11295-013-0692-y

[22] Arús, P., Verde, I., Sosinski, B., Zhebentyayeva, T. and Abbott, A.G. (2012) The Peach Genome. Tree Genetics \& Genomes, 8, 531-547. https://doi.org/10.1007/s11295-012-0493-8

[23] Gu, C., Wang, L., Wang, W., Zhou, H., Ma, B., Zheng, H., et al. (2016) Copy Number Variation of a Gene Cluster Encoding Endopolygalacturonase Mediates Flesh Texture and Stone Adhesion in Peach. Journal of Experimental Botany, 67, 1993-2005. https://doi.org/10.1093/jxb/erw021

[24] Sherman, W.B., Topp, B.L. and Lyrene, P.M. (1990) Non-Melting Flesh for Fresh Market Peaches. Proceedings of the Florida State Horticultural Society, 103, 293-294.

[25] Crisosto, C.H. and Valero, D. (2008) 22. Harvesting and Postharvest Handling of Peaches for the Fresh Market. In: Layne, D.R. and Bassi, D., Eds., The Peach: Botany, Production and Uses, CAB International, Wallingford, 575-596.

https://doi.org/10.1079/9781845933869.0575

[26] Slaughter, D.C., Crisosto, C.H., Hasey, J.K. and Thompson, J.F. (2006) Comparison of Instrumental and Manual Inspection of Clingstone Peaches. Applied Engineering in Agriculture, 22, 883-889. https://doi.org/10.13031/2013.22242

[27] Lukowitz, W., Gillmor, C.S. and Scheible, W. (2000) Positional Cloning in Arabidopsis. Why It Feels Good to Have a Genome Initiative Working for You. Plant Physiology, 123, 795-806. https://doi.org/10.1104/pp.123.3.795

[28] Geuna, F., Maitti, C., Digiuni, S. and Banfi, R. (2004) A Method for Extracting Genomic DNA Suitable for Medium-Throughput Applications from Plant Tissues Rich in Contaminants. Plant Molecular Biology Reporter, 22, 87. https://doi.org/10.1007/BF02773354

[29] Warburton, M.L. and Bliss, F.A. (1996) Genetic Diversity in Peach (Prunus persica L. Batsch) Revealed by Randomly Amplified Polymorphic DNA (RAPD) Markers and Compared to Inbreeding Coefficients. Journal of the American Society for Horticultural Science, 121, 1012-1019.

[30] Iezzoni, A., Weebadde, C., Luby, J., Chengyan, Y., van de Weg, E., Fazio, G., et al. (2010) RosBREED: Enabling Marker-Assisted Breeding in Rosaceae. Acta Horticulturae, 859, 389-394. http://www.actahort.org/books/859/859_47.htm https://doi.org/10.17660/ActaHortic.2010.859.47

[31] RosBREED (2016) Ppe-Texture: DNA Tests for Peach Texture. http://www.rosbreed.org/breeding/dna-tests/peach/texture

[32] Tatsuki, M., Haji, T. and Yamaguchi, M. (2006) The Involvement of 1-Aminocyclopropane-1-Carboxylic Acid Synthase Isogene, $P p-A C S 1$, in Peach Fruit Softening. Journal of Experimental Botany, 57, 1281-1289. https://doi.org/10.1093/jxb/erj097

[33] Hayama, H., Tatsuki, M., Ito, A. and Kashimura, Y. (2006) Ethylene and Fruit Softening in the Stony Hard Mutation in Peach. Postharvest Biology and Technology, 41, 16-21. https://doi.org/10.1016/j.postharvbio.2006.03.006

[34] Pan, L., Zeng, W., Niu, L., Lu, Z., Liu, H., Cui, G., et al. (2015) PpYUC11, a Strong Candidate Gene for the Stony Hard Phenotype in Peach (Prunus persica L. Batsch), Participates in IAA Biosynthesis during Fruit Ripening. Journal of Experimental Botany, 66, 7031-7044. https://doi.org/10.1093/jxb/erv400 
[35] Okie, W.R. and Layne, D.R. (2008) "Scarletprince" and "Julyprince" Peaches. HortScience, 43, 1603-1605.

[36] Haji, T., Yaegaki, H. and Yamaguchi, M. (2005) Inheritance and Expression of Fruit Texture Melting, Non-Melting and Stony Hard in Peach. Scientia Horticulturae, 105, 241-248. https://doi.org/10.1016/j.scienta.2005.01.017

Submit or recommend next manuscript to SCIRP and we will provide best service for you:

Accepting pre-submission inquiries through Email, Facebook, LinkedIn, Twitter, etc. A wide selection of journals (inclusive of 9 subjects, more than 200 journals)

Providing 24-hour high-quality service

User-friendly online submission system

Fair and swift peer-review system

Efficient typesetting and proofreading procedure

Display of the result of downloads and visits, as well as the number of cited articles Maximum dissemination of your research work

Submit your manuscript at: http://papersubmission.scirp.org/

Or contact ajps@scirp.org 